\title{
PENINGKATAN KEKEBALAN SPESIFIK ANTI STREPTOCOCCUS PADA BUDI DAYA IKAN NILA
}

\author{
Hambali Supriyadi*), Desy Sugiani**), dan Uni Purwaningsih**)
}

\begin{abstract}
ABSTRAK
Uji lapang vaksin Streptococcus telah dilakukan dengan tujuan untuk mengetahui efektivitas vaksin dan respon kebal pada ikan nila (Oreochromis niloticus) terhadap rangsangan yang diberikan. Penelitian dilakukan pada keramba jaring apung (KJA). Vaksin yang digunakan adalah vaksin S1N8 dan GM2.4 berupa vaksin yang diinaktivasi dengan formalin 0,3\% Aplikasi vaksin dilakukan secara bertahap yaitu vaksin awal (priming) diberikan melalui rendaman, sedangkan vaksin ulang diberikan melalui suntikan. Dosis vaksin awal yaitu $10 \mathrm{~mL}$ vaksin/100 L air untuk 1.000 ekor ikan direndam selama 15 menit, sedangkan booster diberikan melalui suntikan $0,2 \mathrm{~mL} /$ ekor ikan. Hasil menunjukkan bahwa kombinasi pemberian vaksin priming melalui rendaman dan booster dengan suntikan untuk vaksin S1N8 menghasilkan sintasan paling tinggi $(70,3 \%-72,5 \%)$, apabila dibandingkan dengan vaksin GM2.4 $(59,3 \%$ $62,5 \%$ dan kontrol $(35,5 \%-42,0 \%$.
\end{abstract}

ABSTRACT: The specific immune response of nile tilapia (Oreochromis niloticus) against Streptococcus iniae vaccine. By: Hambali Supriyadi, Desy Sugiani, and Uni Purwaningsih

Field study of vaccines S1N8 and GM2.4 with the aims to evaluate the effectiveness of vaccine and the immune response of nile tilapia (Oreochromis niloticus) against the vaccines. The research have been conducted in floating net cage. Vaccine tested were produced from Streptococcus iniae isolates SIN8 and GM2.4 which was prepared by formalin killed of $0.3 \%(\mathrm{v} / \mathrm{v})$. Vaccine delivery were given in two steps i.e. priming with immersion, and booster through injection. The dose of vaccine for priming was $10 \mathrm{~mL}$ of vaccine $/ 100 \mathrm{~L}$ water immersed for 1,000 fish for 15 minutes. Booster were delivered by injection as much as $0.2 \mathrm{~mL} / f$ ish. The results indicated that combination of vaccine delivering of immersion (priming) and injection (booster) especially for S1N8 vaccine were the highest percent of survival rate $(70.3 \%-72.5 \%)$ as compared with GM2.4 vaccine (59.3\%-62.5\%) and control (35.5\%-42.0\%).

\section{KEYWORDS: immune response, nile tilapia, Streptococcus iniae, vaccine}

\section{PENDAHULUAN}

Penyakit bakterial merupakan salah satu masalah serius yang selalu dihadapi oleh pembudi daya ikan karena penyakit tersebut selain dapat mengakibatkan kematian sekitar 50\%-100\%(Supriyadi \& Taufik, 1981; Taufik, 1992; Supriyadi \& Rukyani, 1990), juga dapat menurunkan mutu daging dari ikan yang terinfeksi berupa borok atau luka, sehingga tidak disenangi oleh konsumen. Penelitian yang dilakukan pada tahun 1991/1992 telah membuktikan bahwa ikan nila dapat terinfeksi oleh bakteri Aeromonas hydrophila dan Enterobactersp. (Supriyadi, 1992).

Penelitian lain yang telah dilaksanakan pada tahun 2002 dan 2003 menunjukkan bahwa ikan nila sangat rentan terhadap infeksi penyakit bakterial antara lain akibat infeksi bakteri Streptococcus iniae. Streptococcosis adalah penyakit akibat infeksi bakteri Strepto-

*) Peneliti pada Pusat Riset Perikanan Budidaya, Jakarta

**) Peneliti pada Balai Riset Perikanan Budidaya Air Tawar, Bogor 
coccus sp. merupakan salah satu penyakit yang cukup membahayakan bagi beberapa spesies ikan budi daya baik air tawar maupun laut di beberapa negara seperti Amerika Serikat pada hibrid ikan Tilapia nilotica x Tilapia aurera (Perera et al., 1994) dan pada ikan Oreochromis niloticus (Bowser et al., 1998). Selain itu Jepang juga melaporkan telah terjadi infeksi streptococcosis pada ikan Saroterodon niloticus (Miyazaki et al., 1984), sedangkan di Spanyol (Toranzo et al., 1994) melaporkan bahwa penyakit streptococcosis telah menginfeksi ikan turbot (Scophthalmus maximus). Penyakit ini telah banyak mengakibatkan kerugian berupa kematian baik pada benih ikan nila maupun ikan nila ukuran konsumsi. Kematian yang diakibatkannya dapat mencapai lebih dari 75\%dari populasi (Perera et al., 1994). Penyakit ini selain sangat potensial merugikan karena menimbulkan kematian juga dilaporkan bahwa penyakit ini merupakan penyakit yang bersifat zoonotic (Holden, 1996 dalam Bowser et al., 1998; Weinsstein et al., 1997 dalam Bowser et al., 1998). Penyakit ini dikatakan lebih banyak terjadi dan menimbulkan wabah pada ikan-ikan yang hidup di lingkungan yang kurang mendukung dan yang dalam keadaan stres.

Penyebaran penyakit ini menurut Supriyadi (2006), telah ditemukan pada beberapa pusat budi daya terutama budi daya ikan nila di Banten, Jawa Barat, Jawa Tengah, dan Daerah Istimewa Yogyakarta. Prevalensi rata- rata tertinggi terdapat di Jawa Barat dan Jawa Tengah. Hal ini dapat dimaklumi karena kedua wilayah tersebut merupakan tempat dengan aktivitas budi daya ikan nila yang cukup tinggi.

Mengingat akan bahayanya penyakit tersebut maka perlu adanya cara pengendalian, berupa pencegahan dengan cara yang efektif dan efisien. Oleh karena itu, dalam laporan ini akan dikemukakan hasil penelitian tentang uji lapang penggunaan dua jenis vaksin anti streptococcosis yang dibuat dari koleksi bakteri Streptococcus iniae lokal, asal Banten (S1N8) dan Jawa Tengah (GM2.4).

\section{BAHAN DAN METODE}

Vaksin yang digunakan dibuat dengan menggunakan koleksi bakteri yang dihasilkan dari penelitian tahun 2002 yaitu S1N8 yang berasal dari Serang Banten, dan GM2.4 berasal dari Waduk Gadjah Mungkur. Sediaan vaksin berupa vaksin yang dimatikan (killed) dengan bahan inaktivasi formalin dengan kadar 0,3\%
Kepadatan antigen ditetapkan pada $10^{11} \mathrm{cfu} /$ $\mathrm{mL}$

Sterilitas vaksin diuji sebelum vaksin tersebut diaplikasikan kepada ikan nila, dengan cara menginokulasikan vaksin tersebut di atas media Brain Heart Infusion Agar (BHIA) dan diamati setelah diinkubasi 24 jam. Uji keamanan vaksin dilakukan dengan cara menyuntikkan vaksin secara intraperitoneal pada 10 ekor ikan nila GIFT, dengan dosis 0,2 $\mathrm{mL} /$ ekor ikan. Pengamatan dilakukan terhadap sintasan ikan uji yang diamati selama 6 hari.

Penelitian uji lapang dilakukan pada Keramba Jaring Apung (KJA) milik Balai Besar Pengembangan Budidaya Air Tawar (BBPBAT) dengan menggunakan jaring yang berukuran $3 \times 3 \times 3$ m dengan kedalaman air 2,5 m. Ikan uji menggunakan ikan nila GIFT ukuran bobot antara 24,42-36,41 g/ ekor, atau ukuran panjang total antara $11,0-13,5 \mathrm{~cm}$. Tiap keramba diisi dengan ikan sebanyak 1.000 ekor dengan ulangan untuk tiap perlakuan 2 (dua) kali. Sebelum ikan diberi perlakuan terlebih dahulu diaklimatisasi selama 10 hari. Ikan yang mati selama proses adaptasi diganti dengan ikan baru supaya jumlah ikan tiap keramba tetap sama. Setelah tidak terjadi lagi kematian selama proses aklimatisasi maka ikan diperlakukan dengan vaksin. Vaksinasi awal (priming) dilakukan dengan cara perendaman dengan dosis vaksin $10 \mathrm{~mL}$ vaksin dilarutkan dalam 100 liter air untuk kepadatan ikan 1.000 ekor dengan lama perendaman 15 menit. Pemberian vaksin ulang (booster) dilakukan 1 (satu) bulan setelah priming, dengan cara injeksi dengan dosis 0,2 $\mathrm{mL}$ vaksin untuk setiap ekor ikan. Penyuntikan dilakukan secara intraperitonial (IP) dengan menggunakan penyuntik otomatis. Pengamatan dilakukan terhadap sintasan ikan uji dan kontrol baik sebelum, maupun setelah uji tantang.

Uji tantang dilakukan di laboratorium dengan cara menyuntik ikan perlakuan sebanyak masing- masing 10 ekor untuk tiap perlakuan dengan menggunakan bakteri Streptococcus iniae diinjeksikan secara intraperitoneal dengan dosis $0,2 \mathrm{~mL} /$ ekor, atau identik dengan $10^{8} \mathrm{cfu} / \mathrm{mL}$. Ulangan tiap perlakuan dilakukan sebanyak 2 kali. Pengamatan dilakukan terhadap sintasan ikan uji selama masa pengamatan 7 hari. Analisis data dilakukan secara deskripif.

Analisis hasil vaksinasi dapat dilakukan dengan melalui uji tantang, dan perhitungan efektivitas vaksin. Untuk mengetahui efek- 
tivitas dari vaksinasi, dianalisis dengan menghitung persentase tingkat kehidupan relatif (Relatif per cent survival/RPS) menggunakan metode Ellis (1988) selama masa pengamatan 7 hari, dengan rumus sebagai berikut:

RPS $=1-\frac{\text { mortalitas ikan yang divaksin }}{\text { mortalitas ikan kontrol }} \times 100$

Uji titer antibodi dilakukan setelah vaksinasi kedua (booster). Ikan yang digunakan telah melewati masa pemeliharaan selama satu bulan setelah booster. Darah diambil sebanyak 0,5-1 $\mathrm{mL}$ dari masingmasing perlakuan, dan diambil serumnya. Kemudian serum tersebut diencerkan dengan pengenceran berganda (double dillution) dan dititrasi dengan menggunakan antigen pada mikrotitre plate. Pengamatan dilakukan terhadap ada atau tidak terjadinya aglutinasi pada tiap lubang mikrotiter plate.

\section{HASIL DAN BAHASAN}

Hasil pengamatan terhadap kematian ikan selama masa adaptasi dapat dilihat pada Gambar 1. Selama masa pengamatan, secara visual nampak bahwa jaring III dan IV memiliki tingkat kematian yang lebih tinggi bila dibandingkan dengan jaring yang lainnya.

Hal ini diduga bahwa kondisi awal ikan kurang baik ditambah dengan proses penanganan ikan selama pengangkutan sehingga banyak menimbulkan stres yang diindikasikan dengan rendahnya respon terhadap pakan, luka pada tubuh ikan, dan ini memberi peluang untuk terinfeksi dengan jasad patogen lainya yaitu jamur, dan hal ini terjadi pada hari $1-4$ yang diikuti dengan jumlah kematian yang cenderung tinggi. Namun pada hari ke- 6 sampai dengan hari ke11 jumlah ikan yang mati cenderung menurun. Untuk mengatasi masalah tersebut dan untuk menjamin bahwa ikan yang digunakan layak untuk penelitian maka dilakukan aklimatisasi yang cukup lama. Hanya ikan yang benar- benar sehat yang kemudian digunakan untuk uji efektivitas vaksin.

\section{Pengujian Sterilisasi dan Keamanan Vaksin}

Hasil pengamatan terhadap sterilitas vaksin ternyata tidak menunjukkan adanya bakteri Streptococcus iniae dan bakteri kontaminan lain yang tumbuh pada media kultur. Keadaan tersebut menandakan bahwa vaksin tersebut steril, tidak mengandung baik bakteri yang berasal dari materi pembuat vaksin maupun bakteri kontaminan lainnya. Sedangkan data hasil pengamatan terhadap keamanan vaksin ternyata menunjukkan bahwa kedua vaksin tersebut (GM2.4 dan S1N8) tidak mengandung bahan beracun yang berasal dari proses pembuatan vaksin tersebut baik yang berupa produk luaran sel

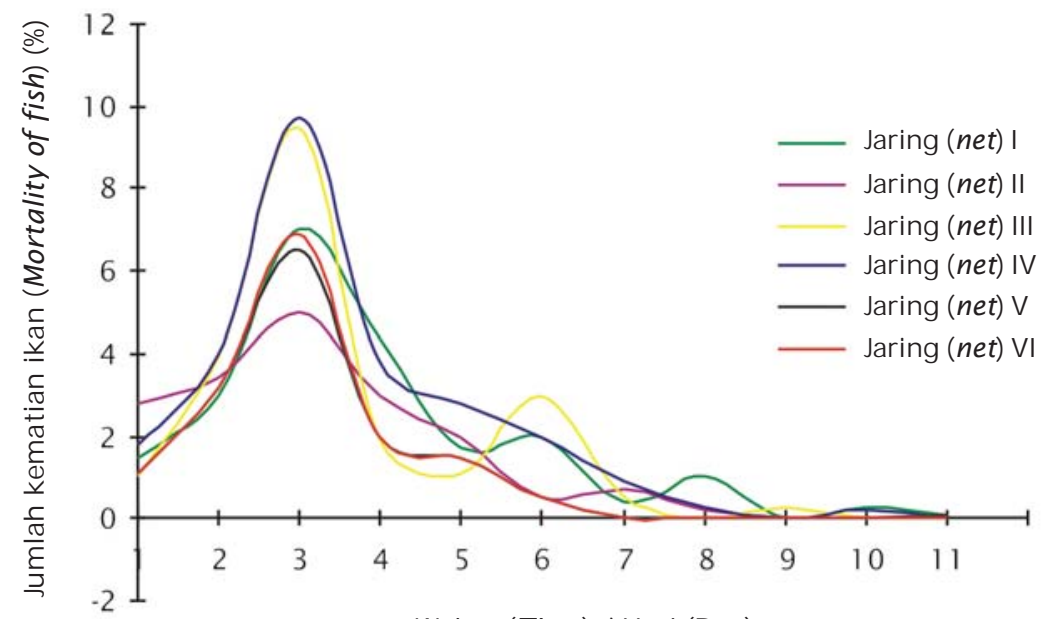

Waktu (Time) / Hari (Day)

Gambar 1. Persentase jumlah kematian harian ikan nila untuk tiap jaring selama masa adaptasi

Figure 1. Daily percentage of mortality of fish for each cage during acclimatization 
(extracellular product) maupun yang berasal dari formalin yang digunakan sebagai bahan inaktivasi vaksin yang dapat menyebabkan kematian pada ikan nila. Hal tersebut berlangsung sampai masa pengamatan 6 hari.

Selain itu terbukti juga bahwa proses pemberian vaksin melalui suntikan tidak menyebabkan timbulnya gangguan pada ikan uji. Dengan kata lain proses penyuntikan telah dilakukan dengan prosedur yang aman dan penanganan ikan selama proses pengujian telah dilakukan dengan baik.

Hasil uji lapang terhadap kedua jenis vaksin menunjukkan bahwa potensi vaksin dalam menimbulkan respon kekebalan terlihat dengan perbedaan antara ikan yang divaksin dengan yang tidak divaksin, baik sebelum uji tantang maupun setelah uji tantang.

Tingginya sintasan ikan nila yang diberi perlakuan vaksinasi dengan ikan kontrol sangat dipengaruhi oleh pemaparan antigen pada proses vaksinasi. Proses pemberian antigen melalui injeksi intra peritoneal (IP), telah merangsang respon imun spesifik pada ikan uji terhadap bakteri S. iniae. Hal ini dibuktikan dengan tingginya sintasan ikan yang divaksinasi (60\%-70\%) bila dibandingkan dengan kontrol (30\%). Perbandingan sintasan ikan yang divaksinasi dengan vaksin S1N8 dan GM2.4 serta kontrol dapat dilihat pada Gambar 2.
Dari hasil pengamatan di lapangan menunjukkan ikan kontrol ternyata lebih mudah mengalami infeksi penyakit dan kematian. Adapun gejala klinis yang paling umum terjadi pada ikan adalah bola mata keruh dan menonjol, warna tubuh yang lebih gelap, serta pergerakan yang lamban dan respon refleks yang rendah. Gejala tersebut menunjukkan adanya infeksi bakteri Streptococcus iniae.

Dari kisaran persentase tingkat sintasan ikan uji, dapat dilihat bahwa ikan yang diperlakukan dengan vaksin S1N8 memiliki kekebalan yang lebih tinggi apabila dibandingkan dengan ikan yang diperlakukan dengan vaksin GM2.4. Vaksin S1N8 mampu merangsang timbulnya daya tahan tubuh lebih tinggi sehingga menimbulkan perbedaan persentase tingkat sintasan $10,50 \%$ terhadap vaksinasi GM2.4, dan 32,65\%terhadap kontrol. Sedangkan vaksin GM2.4 hanya mampu mempertahankan perbedaan tingkat sintasan $22,15 \%$ terhadap ikan kontrol.

Tinggi rendahnya daya tahan tubuh yang dihasilkan juga akan tergantung pada metode pemberian vaksin. Pemberian vaksin ulang (booster) melalui suntikan (injection) kelihatannya memiliki beberapa keuntungan antara lain antigen dapat masuk ke dalam tubuh ikan sesuai dengan dosis yang dibutuhkan.

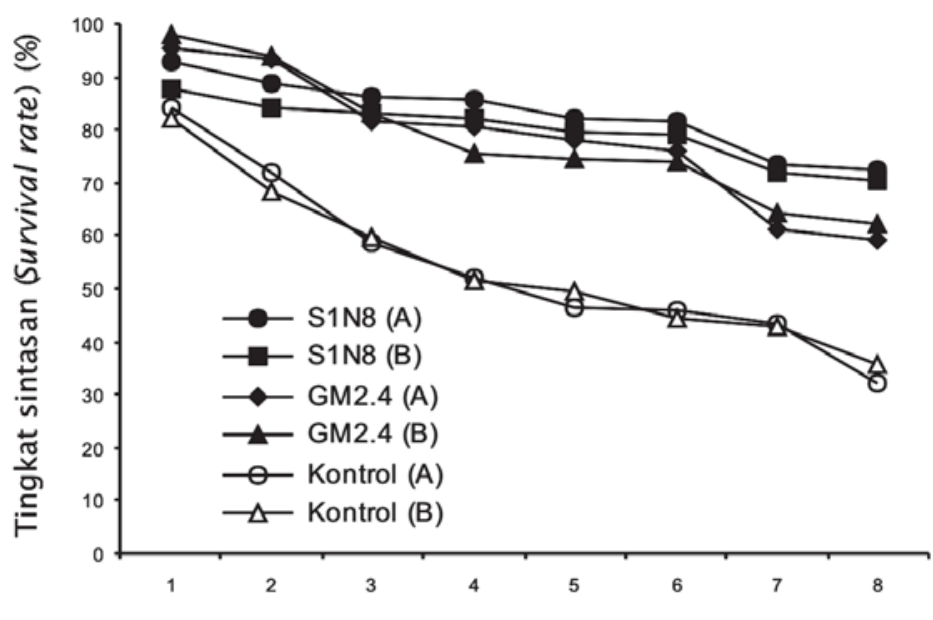

Waktu pengamatan (observations time) (minggu/week)

Gambar 2. Grafik perbandingan sintasan ikan yang divaksinasi dengan vaksin S1N8 dan vaksin GM2.4 serta kontrol sebelum uji tantang

Figure 2. Survival rate of fish vaccinated with S1N8 and GM2.4 vaccines as well as control 
Namun demikian metode tersebut juga memiliki kelemahan- kelemahan yaitu antara lain kurang tepat digunakan pada ikan yang memiliki ukuran kecil dan dalam jumlah yang sangat banyak, sehingga aplikasi di kalangan pembudi daya akan mendapat sedikit kesulitan. Namun demikian Smith (1988) menjelaskan bahwa walaupun banyak hal yang telah membatasi aplikasi vaksin dengan metode penyuntikan, namun kekurangan tersebut dapat diatasi dengan vaksinasi yang diberikan pada ikan yang memiliki keseragaman ukuran, diberikan pada ikan yang tidak dalam keadaan stres setelah penanganan. Selain itu proses penyuntikan bisa dipermudah dan dipercepat dengan menggunakan automatik injektor.

Hasil perhitungan persentase tingkat kehidupan relatif dapat dilihat pada Tabel 1 . Dari tabel tersebut dapat dilihat bahwa ternyata penggunaan vaksin melalui suntikan terutama vaksin S1N8 cukup efektif. Ellis (1988) mengatakan bahwa uji vaksin baik di lapangan maupun di laboratorium, suatu vaksin bisa dikatakan efektif apabila tingkat kematian pada kontrol paling sedikit $60 \%$ sedangkan pada ikan yang divaksin harus di bawah $24 \%$

Tingkat kematian ikan yang divaksinasi GM2.4 (46,1\%-37,5\%), tingkat kematian ini lebih tinggi bila dibandingkan dengan ikan yang divaksinasi S1N8 (27,5\%-29,8\%), sedangkan kontrol 58,0\%-64,5\% Tingkat kehidupan relatif (RPS) untuk ikan yang divaksinasi S1N8 adalah 52,6\%-54,0\% sedangkan tingkat kehidupan relatif untuk ikan yang divaksin GM2.4 adalah 41,9\%-42,0\% berarti vaksin S1N8 menghasilkan tingkat kehidupan relatif $11,35 \%$ lebih tinggi bila dibandingkan vaksin GM2.4. Dari data di atas walaupun tidak tercapai seperti apa yang disyaratkan oleh Ellis (1988), namun angka yang terdapat pada tabel hampir mendekati persyaratan tersebut.

Dari uji titer antibodi menunjukkan ikan kontrol memiliki titer antibodi yang rendah bila dibandingakan dengan ikan yang divaksinasi (Tabel 2), sedangkan untuk nilai titer yang tertinggi terdapat pada ikan dengan vaksinasi menggunakan vaksin S1N8, hal tersebut juga dibuktikan dengan tingkat sintasan ikan uji yang tinggi.

\section{KESIMPULAN DAN SARAN}

jkan nila mampu merespon rangsangan antigen yang diberikan melalui perendaman, dan vaksin ulang (booster) melalui suntikan, sehingga dapat menimbulkan daya tahan yang cukup tinggi yang digambarkan dengan hasil sintasan yang lebih tinggi. Vaksin S1N8 ternyata dapat menghasilkan sintasan yang lebih tinggi apabila dibandingkan dengan vaksin GM2.4.

Perlu diciptakan aplikasi vaksin yang mudah dilakukan oleh pembudi daya ikan selain dengan cara penyuntikan.

\section{UCAPAN TERIMA KASIH}

Keberhasilan penelitian ini berkat bantuan dari berbagai pihak oleh karena itu pada kesempatan ini kami mengucapkan terima kasih kepada Kepala Balai Besar Pengembangan Budidaya Air Tawar beserta staf yang telah

Tabel 1. Perbandingan tingkat sintasan relatif antara ikan uji yang di vaksinasi dengan vaksin S1N8 dengan GM2.4.

Table 1. Relatif per cent survival of fish vaccinated with S1N8 and GM2.4 vaccine, and unvaccinated fish.

\begin{tabular}{lcccc}
\hline \multirow{2}{*}{$\begin{array}{c}\text { Jenis vaksin } \\
\text { Vaccine type }\end{array}$} & $\begin{array}{c}\text { Ulangan } \\
\text { Replicated }\end{array}$ & $\begin{array}{c}\text { Tingkat kematian rata-rata (\%) } \\
\text { Average mortality (\%) }\end{array}$ & RPS \\
\cline { 3 - 4 } & & $\begin{array}{c}\text { Vaksin } \\
\text { Vaccine }\end{array}$ & $\begin{array}{c}\text { Kontrol } \\
\text { Control }\end{array}$ & \\
\hline GM2.4 & 1 & 46.1 & 58.0 & 41.9 \\
& 2 & 37.5 & 64.5 & 42.0 \\
& Rataan (Average) & 41.8 & 61.2 & 41.9 \\
\hline \multirow{2}{*}{ S1N8 } & 1 & 27.5 & 58.0 & 52.6 \\
& 2 & 29.7 & 64.5 & 54.0 \\
& Rataan (Average) & 28.6 & 61.5 & 53.3 \\
\hline
\end{tabular}


Tabel 2. Hasil uji titer antibodi dari serum ikan nila yang divaksin dengan vaksin S1N8 dan GM2.4 serta kontrol

Table 2. Result of antibody titer test of fish vaccinated with S1N8 and GM2.4 vaccines and control

\begin{tabular}{|c|c|c|c|c|c|c|c|c|c|c|c|c|}
\hline \multirow{2}{*}{$\begin{array}{l}\text { Waktu } \\
\text { Time }\end{array}$} & \multirow{2}{*}{$\begin{array}{l}\text { Perlakuan } \\
\text { Treatments }\end{array}$} & \multicolumn{11}{|c|}{ Nilai titer antibodi (The value of antibody titer) } \\
\hline & & 1:1 & $1: 2$ & $1: 4$ & $1: 8$ & 1:16 & $1: 32$ & 1:64 & 1:128 & 1:256 & 1:512 & $1: 1024$ \\
\hline \multirow[t]{3}{*}{ I } & Kontrol & + & + & + & - & - & - & - & - & - & - & - \\
\hline & S1N8 & + & + & + & + & + & - & - & - & - & - & - \\
\hline & GM2.4 & + & + & + & + & + & - & - & - & - & - & - \\
\hline \multirow[t]{3}{*}{ II } & Kontrol & + & + & + & + & + & - & - & - & - & - & - \\
\hline & S1N8 & + & + & + & + & + & + & + & + & + & + & \\
\hline & GMR.4 & + & + & + & + & + & + & + & + & + & - & - \\
\hline
\end{tabular}

Note: I = 2 minggu setelah vaksin awal ( 2 weeks after priming)

II =2 minggu setelah vaksin ulang ( 2 weeks after booster)

$(+)=$ terjadi aglutinasi (agglutinated)

$(-)=$ tidak terjadi aglutinasi (non agglutinated)

membantu dan menyediakan jaring apung untuk kelancaran pelaksanaan penelitian ini.

\section{DAFTAR PUSTAKA}

Bowser, P.R., G.A. Wooster, R.G. Getchell, and M.B. Timmons. 1998. Streptococcus innae Infection of Tilapia Oreochromis niloticus in a recirculation production facility. Journal of The World Aquaculture. 29(3): 335-339.

Ellis, A.E. 1988. Fish Vaccination. Academic Press. Harcout Brace Jovanovich, Publisher. London. $255 \mathrm{pp}$.

Miyazaki, T., S.S. Kubota., N. Kaige, and T. Miyashita. 1984. A Histopathology Study of Streptococcal disease in Tilapia. Fish Pathology. 19(3): 167-172.

Perera, R.P., S.K. Johnson., M.D. Collins, and D.H. Lewis. 1994. Streptococcus iniae Associated with Mortality of Tilapia nilotica $\times T$. aurea Hybrids. J. Aquatic Animal Health. 6: 335-340.

Smith, P.D. 1988. Vaccianation against Vibriosis. Academic Press Haracourt Brace Jovanovich. London. p. 67-79.

Supriyadi, H. dan P. Taufik. 1981. Identifikasi dan cara penanggulangan penyakit bakterial pada ikan lele (Clarias batrachus). Bull. Perik. Air Tawar. I(3): 447-454.
Supriyadi, H. dan A. Rukyani. 1990. Immunopropilaksis dengan cara vaksinasi pada usaha budidaya ikan. Makalah Seminar Nasional Ke II, Penyakit Ikan dan Udang, Bogor. 16- 18 Januari 1990. 7 pp.

Supriyadi, H. 1992. Identifikasi dan Cara Penanggulangan Penyakit Bakterial Pada Ikan Nila. Pros. Seminar Hasil Pen. Perik. Air Tawar 1991/ 1992 Cipayung 20- 22 Oktober 1992. Hambali Supriyadi et al. (eds.). Balai Penelitian Perikanan Air Tawar. Bogor. Pusat Penelitian dan Pengembangan Perikanan. Badan Penelitian dan Pengembangan Pertanian. p. 59-63.

Supriyadi, H. 2006. Infeksi bakteri Streptococcus iniae pada ikan budi daya di Indonesia. Media Akuakultur. I(2): 71-73.

Taufik, P. 1992. Penyakit pada ikan gurame (Osphronemus gouramy Lac.) dan penanggulangannya. Makalah pada Pertemuan Aplikasi Teknologi Budidaya Ikan Gurame, 24-26 Agustus 1992 di Yogyakarta. 6 pp.

Toranzo, A.E., S. Devesa, P. Heinen, A. Riaza, S. Nunez, and J.L. Barja. 1994. Streptococcosis in cultured turbot caused by an Enterococcus - like bacterium. Bull. Eyr. Ass. Fish. Pathol. 14(1): 19-23. 